\title{
45. Migrants to repopulate depopulated villages - Riace in Calabria, Italy and its mayor Mimmo Lucano Pippo Ranci
}

\section{“CLIMATE MIGRANTS”}

According to a recent World Bank report (2018), in only three regions Sub-Saharan Africa, South Asia and Latin America, which together represent 55 percent of the developing world's population - climate change will push over 143 million people - or around 2.8 percent of the population of these three regions - to migrate within their countries by 2050 . These flows will be additional with respect to the well-known, and generally cross-border, flows of refugees and migrants fleeing war, poverty and oppression. It can be imagined that a share of these climate-induced migrations may well turn from internal to cross-border, according to the local conditions and developments. Climate mitigation and policies to prevent migration may reduce these impressive flows but will not eliminate them. Adaptation must be faced in various ways, including an acceptable settlement of migrants.

In this chapter we tell an unusual story of migrants from various Mediterranean and African countries settling in an area called Locride, on the southeastern coast of Calabria, Italy.

\section{CALABRIA}

Calabria is one of the poorest regions in Italy, although it is rich in history. Inhabited by Italic populations, from the eighth century BC it was an important centre of Greek civilization (Magna Graecia) and then of the Roman empire until the fifth century AD. Occupied and influenced by Byzantines, Normans and Arabs, it lived through centuries of decadence under French and Spanish rule. Life did not improve under a Piedmont-dominated kingdom of Italy, when poverty pushed hundreds of thousands of people each year to look for a better life in North and South America, then in Western Europe. After 
World War II, the main destination was Northern Italy. The population of the Calabrian diaspora is estimated as two to three times the population of Calabria itself. The southeastern coast of Calabria can be reached from Libya and from the Eastern Mediterranean easily. It is geographically suited to uncontrolled immigration.

The social fabric has been torn between institutions loyal to a foreign or anyway extraneous political centre and local mafias who imposed their burden and paralysed economic growth and social progress. Migrations left many houses empty and agricultural land abandoned.

\section{RIACE AND MAYOR LUCANO}

In the midst of Locride lies Riace, a village that came to world fame as the place where two Greek bronze statues of warriors from the middle of the fifth century BC were found on the seabed in 1972. It was a village of 1600 residents according to the 2001 census, down from a level of 2400 in the 1921 census.

In 1998, a boat carrying Kurdish refugees landed on the Riace shore. Others followed, and although most of them went on towards other Italian and European destinations, many settled. In a decade, thousands of migrants arrived (an estimate is 6000), of whom 450 settled, bringing new life to the village.

This settlement has been mainly due to the courageous and stubborn action of Domenico (Mimmo) Lucano. Lucano was born nearby, moved early in his life to Riace, then to Rome as a university student and to Northern Italy as a teacher. He moved back to Riace, was a human rights activist from the 1990s and became mayor of Riace in 2004. In this role he supported the settling of migrants and refugees in the small municipality, where the population was old on average and many homes, abandoned by people who had migrated away from Italy in the previous decades, were available.

Lucano was active in having the old buildings restored and made available to the incoming population of mainly young people. He organized their activity in opening or reopening artisan and textile shops, in providing food and lodging to visitors in the homes. He secured government and private funds for training. With the arrival of new children, the planned closure of the local school could be avoided. The village flourished again as old activities were resumed by the new residents.

Economically, the new life was largely based on subsidies to specific projects and to the ordinary public cash support to immigrants (35 euros/day) that would have been paid out even if the migrants had been kept under custody and de facto prevented from doing any useful activity, as happens in many refugee camps in the world. 
In order to get the new activities started, a local pseudo-currency was introduced by the Riace municipality, together with a number of municipalities of the area. The municipal administrations were in charge of handing out the 35-euro subsidy, but government funds were often late, sometimes by six or seven months. Lucano printed a local currency, carrying images of historic revolutionaries like Che Guevara and of mafia victims like Peppino Impastato: the shopkeepers accepted the notes. The initiative, although clearly useful, was criticized.

Waste collection contracts had been traditionally awarded to local small companies set up by the local mafia. Lucano chose a couple of new cooperatives who employed the migrants. They were flexible enough to use donkeys to do their job along the narrow streets where no van could enter.

Old buildings were adapted for hosting up to 100 visitors. A new farm, with livestock both for production and for teaching, was set up and managed by migrants themselves according to biological methods.

\section{CELEBRITY AND CONTRAST}

Lucano's innovative approach to dealing with refugees in the context of the European migrant crisis gained worldwide attention. Lucano came third in the 2010 competition for the World Mayor Prize run by the World Mayor Foundation, ahead of mayors in many important cities. Yet, as the saying "nemo propheta in patria" (no man is a prophet in his own land) goes, Lucano met strong local opposition, of three types.

First, he was dangerously opposed by the local mafia. In 2009, shortly after his first re-election as mayor, he was shot at through the window of a restaurant and two of his dogs were poisoned. Second, his administration of the Riace municipality was censured on the grounds of administrative irregularities. These accusations were not completely groundless: the permanent emergency created by the number and movement of the migrants, the innovative activities, the rigidity of the legal frame and slowness of the public administration, the difficult local relations in an area traditionally dominated by the mafias, made it almost impossible for him to avoid incurring some irregularities, at least formal. Third and most effective, he has been the target of denigration and obstruction by the Interior Minister and political leader Matteo Salvini during his tenure from June 2018 to September 2019. Lucano was taken to court more than once on the basis of various accusations, including accounting irregularities, the waste collection service assigned without a regular tender, and even accusations of attempts to celebrate marriages between a migrant and a local resident with the purpose of granting the migrant an Italian citizenship. Although the judiciary rejected some of these accusations, Lucano was suspended from office and arrested on the basis of recent legislation, 
introduced by the Salvini-dominated government, that makes favouring illegal immigration a criminal offence. His house arrest was converted into an order to stay away from Riace.

Inquiries and trials have been ongoing for long. No accusation was made, though, regarding pursuit of his personal interests: in fact, all the time it has been evident that he systematically sacrificed them to his humanitarian mission and, possibly, his ambition to lead a new model of immigrant integration.

The Salvini-dominated government ${ }^{1}$ reduced or eliminated the financial provisions on which the Riace experiment was based and ordered the Riace municipality to give back all the transfer payments that had been used irregularly. Most initiatives had to be discontinued, many social enterprises were forced to close. Under the new conditions created by the anti-immigration legislation, many migrants who had settled in Riace left for other destinations. The whole experiment was destroyed. ${ }^{2}$

A film on Lucano's life had been commissioned by the Italian state television. It was produced in 2017, but its circulation was forbidden by government in 2018.

\section{HOPE SUPPRESSED, FOR THE TIME BEING}

New municipal elections were held in May 2019. A new mayor was elected from a local, right-wing list, with a programme of going "back to normal life", of keeping the number of new settlers low and of taking primary care of services to the residents.

Two aspects of the Riace model have attracted the attention of some experts, however. While most public refugee camps allow permanence for a limited time, usually six months, integration requires a longer stay, and Riace provided acceptance without a time limit. Moreover, distribution of cash (even through the expedient of the local currency) is more conducive to integration than distribution of food. Both aspects have been seen as important and positive in research referred to other situations (Taylor, 2016).

\section{WILL THE MODEL SURVIVE?}

The repressive attitude of government started changing in September 2019 following a political turnaround that led to a new coalition government that excluded Salvini's Lega. New developments are possible.

Whatever happens to Riace, a number of local initiatives, similar to the Riace experiment, have been undertaken in other locations. Interestingly enough, in September 2019, the government of Molise, the smallest region in Southern Italy, announced subsidies to people who moved into municipalities having fewer than 2000 residents and who started a new business. ${ }^{3}$ 
The "Riace model" is not unique. In 2015, the arrival of only ten Syrian children with their families saved the primary school of the German village Golzow, near the Polish border, from having to close down the first grade, and produced a successful case of integration, initial opposition notwithstanding. This tiny episode made news since Golzow (820 inhabitants) and its primary school were well known as the backdrop for "The Children of Golzow," an epic Communist-era documentary that followed a cohort of first graders through decades of life behind the Iron Curtain. ${ }^{4}$

The problem of settling waves of immigrants, moving for various reasons, among which is climate change, will remain, in Italy and elsewhere, on a level that requires new and creative solutions. The simple idea of migrants settling in depopulated regions, where a local culture can be revived through cross-fertilisation, will deserve further attention.

\section{NOTES}

1. The cabinet led by Giuseppe Conte, appointed 1 June 2018 and dissolved 5 September 2019, was formed by a coalition of Movimento 5 Stelle and Lega. The leader of the latter party, Matteo Salvini, held the position of Interior Minister and was very active in opposing Italian acceptance of migrants.

2. After a lower court decision and an appeal by the Ministry, on 7 June 2020 the Council of State has finally decided that the closure of the Centres of the Protection System for Refugees and Asylum Seekers (SPRAR), including the one of Riace, that was decided by the Interior Ministry in 2018, was illegal. On 7 July 2020 the Court for the Revision of measures restricting personal freedom (Tribunale del Riesame) has decided that the measures applied to mayor Lucano were unfounded.

3. Silvia Marchetti (2019), "These Italian towns in Molise will pay you $\$ 27,000$ to move there", CNN Travel, 12 September, accessed 19 August 2020 at https:// edition.cnn.com/travel/article/molise-italy-pay-to-move/index.html.

4. Katrin Bennhold (2019), "Syrian children saved a German village. And a village saved itself", The New York Times, 19 September, accessed 19 August 2020 at https://www.nytimes.com/2019/09/19/world/europe/germany-golzow-syria -refugees.html.

\section{REFERENCES}

Taylor J.E. (2016), "Research: refugees can bolster a region's economy”, Harvard Business Review, 5 October.

World Bank (2018), Groundswell: Preparing for Internal Climate Migration, Washington, DC: World Bank. 